DOI: $10.26907 / 2311-2042-2021-17-2-25-44$

\title{
COMPARISONS WITH A "COLOR" COMPONENT AS A MEANS OF HUMAN ASSESSMENT (BASED ON THE TATAR AND RUSSIAN LANGUAGES)
}

\author{
Ramziya Marsovna Bolgarova, \\ Kazan Federal University, \\ 18 Kremlyovskaya Str., Kazan, 420008, Russian Federation, \\ ramzija5@yandex.ru. \\ Raushaniya Sagdatzyanovna Nurmukhametova, \\ Kazan Federal University, \\ 18 Kremlyovskaya Str., Kazan, 420008, Russian Federation, \\ rsagadat@yandex.ru.
}

\begin{abstract}
This article examines comparative constructions with a color component in the Tatar and Russian languages in a comparative aspect.

The purpose of this research is to study comparisons with color components as a means of describing a person's appearance and character. Examples from the Written Corpus of the Tatar Language, the National Corpus of the Russian Language were used as research materials. Color component comparisons are used to describe natural features of people's appearance and external signs of their physical and psychological state. These figurative means can create either a positive or a negative image, depending on the compared object and image.

The theoretical and practical value of this work is the possibility of using its main results in studying linguoculture and lexicology of the Tatar and Russian languages.
\end{abstract}

Key words: Tatar language, Russian language, comparison, color components, human appearance.

\section{Introduction}

All ideas of people about the world around them are formed in their consciousness and are largely explained by the associative nature of thinking. The image of a person is one of the main images both in depicting the world belonging to all people and in depicting their national world. Therefore, the study of stable comparative linguistic units, depicting people, allows us to fully represent their image reflected in the language.

We must say that the human image is a manifestation of the national perception of the world. Representatives of different cultures have their own ideas of the surrounding environment, perceiving information about the world in their own way. According to Humboldt, "different languages are not only different names for the same subject, but also different views on them" [Humboldt, p. 154]. Therefore, the world image can be verbally described only taking into account national and cultural characteristics of language.

As noted by A. Potebnya, "thanks to the word, a person again recognizes what is in his mind. He simultaneously creates a new world out of chaos and strengthens his power to expand the boundaries of this world" [Potebnia, p. 302].
Stable comparisons are units that are actively used in the Tatar and Russian languages. They contain figurative and expressive speech means, in most cases the emotions of the speaker or writer. As different layers of phraseology, comparisons accumulate the centuries-old experience of the population. Also, comparisons are based on cultural associations, on linguistic and cultural experiences.

\section{Materials and research methods}

Our research is based on examples from the Written Corpus of the Tatar Language and the National Corpus of the Russian Language.

We used the corpus examples describing a person, formed by matching color components that include auxiliary words кебек (kebek) and как (kak), which are often used in both languages, and comparisons formed directly with the auxiliary word төсле (tesle).

In the article, we used the method of observation, as well as comparative, descriptive and semantic analyses. 


\section{Discussion}

You can get a great amount of information on a person's appearance by determining one's nationality, gender, age, and giving personal characteristics. In general, the appearance of a person, the features of description speak volumes as to the national culture. Usually, when describing a person, we use both positive and negative connotations. In this work, comparisons with a color component in Tatar and Russian are analyzed as a means of describing and evaluating a person's appearance.

Colors are used to compare someone with a specific object or phenomenon in order to give additional characteristics to the features of a person's external appearance and inner world. Representatives of different cultures perceive and evaluate the same color in different ways depending on the meaning.

There is a deep connection between the symbolism of colors and human consciousness, history, cultural and social life. Colors can express different meanings, evoke different feelings and create associations; thus, they create special and peculiar changes in the human mental world. Associations are connected with the features of personal, national, religious, etc. perception of the world. Since ancient times, people have paid special attention to colors in the beliefs of the people, their ancient legends, works of oral folk art and religious teachings.

A characteristic feature of the color semantics is polysemy. Color contains many different meanings, and these qualities are reflected in set phrases.

Our scientific research is focused on color comparisons that have identity and are often used in the Tatar and Russian languages (colors: white, black, red, green and blue).

In the culture of mankind, white and black are considered to be the most ancient colors. In the Tatar and Russian languages, the names of these colors are encountered quite often in comparisons, which can be explained by their cognitive and cultural significance.

White color

$\mathrm{AK}(\mathrm{AK})$

\begin{tabular}{|c|c|}
\hline $\begin{array}{l}\text { 1) Кар, сөт төсендәге; } \\
\text { киресе: кара. } \\
\text { 2) Үз төсен югалткан, } \\
\text { чал, чаларган, көмеш } \\
\text { төсле. } \\
\text { 3) Ялтырап торган } \\
\text { көмешсыман төстәге, }\end{array}$ & $\begin{array}{l}\text { 1) The colors of snow, } \\
\text { milk; opposite: black. } \\
\text { 2) Lost its color, gray- } \\
\text { haired, silver. } \\
\text { 3) Light silver color, on } \\
\text { top of which nickel is }\end{array}$ \\
\hline
\end{tabular}

\begin{tabular}{|c|c|}
\hline өстеннән никель & applied. \\
\hline $\begin{array}{l}\text { 4) Борчылудан, } \\
\text { каушаудан, авырудан } \\
\text { йөзе үзгәргән, төсе, } \\
\text { чырае киткән, } \\
\text { агарынган. }\end{array}$ & $\begin{array}{l}\text { 4) A face pale with } \\
\text { excitement, confusion, } \\
\text { illness, pain. }\end{array}$ \\
\hline $\begin{array}{l}\text { 5) махс. Ике яки өч } \\
\text { сүздән торган зоологик } \\
\text { hәм биологик } \\
\text { терминнарның } \\
\text { (атамаларның) беренче } \\
\text { кисәге. }\end{array}$ & $\begin{array}{l}\text { 5) prof. The first part of } \\
\text { zoological and } \\
\text { biological terms } \\
\text { (names), consisting of } \\
\text { two or three words. }\end{array}$ \\
\hline $\begin{array}{l}\text { 6) күч. Чиста, керсез, } \\
\text { пычранмаган, юылган } \\
\text { (кием-салым турында). }\end{array}$ & $\begin{array}{l}\text { 6) fig. m. (figurative } \\
\text { meaning). Clean, not } \\
\text { dirty, washed (about } \\
\text { clothes). }\end{array}$ \\
\hline 7) күч. тар. & 7) fig. $m$. (in the narrow \\
\hline Революциягә һәм & sense). A man who was \\
\hline $\begin{array}{l}\text { Совет хөкүмәтенә } \\
\text { каршы булган. }\end{array}$ & $\begin{array}{l}\text { against the revolution } \\
\text { and the Soviet } \\
\text { government. }\end{array}$ \\
\hline $\begin{array}{l}\text { 8) күч. Алдынгы; } \\
\text { укымышлы, } \\
\text { прогрессив. }\end{array}$ & $\begin{array}{l}\text { 8) fig. m. Advanced; } \\
\text { educated, progressive. }\end{array}$ \\
\hline 9) күч. Язмыйча, буш & 9) fig. $m$. Leaving empty \\
\hline $\begin{array}{l}\text { калдырып, фикернең } \\
\text { тәмамланмавына, } \\
\text { яшерен эчке мәгънә } \\
\text { булуына ишарә иткән } \\
\text { [Татар теленең } \\
\text { аңлатмалы сүзлеге]. }\end{array}$ & $\begin{array}{l}\text { lines, indicating that the } \\
\text { thought is not finished, } \\
\text { there is a hidden inner } \\
\text { meaning [Explanatory } \\
\text { Dictionary of the Tatar } \\
\text { Language]. }\end{array}$ \\
\hline
\end{tabular}

БЕ́ЛЫЙ (BELIY), -ая, -ое; бел, бела, бело и бело

\begin{tabular}{|c|c|}
\hline $\begin{array}{l}\text { 1. Цвета снега или } \\
\text { мела. } \\
\text { 2. полн. Светлый, в } \\
\text { противоположность } \\
\text { чему-н. более тёмному, } \\
\text { именуемому чёрным. } \\
\text { 3. полн. В первые годы } \\
\text { гражданской войны: } \\
\text { относящийся к } \\
\text { вооружённой борьбе за } \\
\text { восстановление } \\
\text { законной власти в } \\
\text { России. } \\
\text { 4. белый, -ого, муж. То } \\
\text { же, что белогвардеец. } \\
\text { 5. полн. Со светлой } \\
\text { кожей (как признак } \\
\text { расы). Цветные и } \\
\text { белые (сущ.) }\end{array}$ & $\begin{array}{l}\text { 1. Colors of snow or } \\
\text { chalk. } \\
\text { 2. Full m. Light, as } \\
\text { opposed to something } \\
\text { darker; opposite: black. } \\
\text { 3. Full m. In the early } \\
\text { years of the Civil War: } \\
\text { related to the armed } \\
\text { struggle for the } \\
\text { restoration of legal } \\
\text { power in Russia. } \\
\text { 4. The same as the } \\
\text { White Guard. } \\
\text { 5. Full m. With fair skin } \\
\text { (as a sign of race). } \\
\text { Colored and white } \\
\text { (noun) [Ozhegov's }\end{array}$ \\
\hline
\end{tabular}




\begin{tabular}{|l|l|}
\hline $\begin{array}{l}\text { [Толковый словарь } \\
\text { Ожегова]. }\end{array}$ & $\begin{array}{l}\text { Explanatory } \\
\text { Dictionary]. }\end{array}$ \\
\hline
\end{tabular}

Associations containing the "white" component in the Tatar language are actively used to describe one's body, face, teeth, hands, hair, beard, mustache, etc. As an object of comparison, words snow, milk, sugar, cotton, swan, turnip, canva are often used. For example:

Иптәиләр, ишкәкләргә ныграк басыгыз! дип пышылдый Искәндәр, һәм караңцгыда аның кар кебек ак тешләре ялтырап китәләр [Taтар теленең язма корпусы] (Comrades, pull on the oars harder! - Iskandar whispers, and his teeth, as white as snow, shine in the darkness [Corpus of Written Tatar]);

Йөзләрена таңуның алсу төсе кунган, иикәр кебек ак йөзле Любаша аерылышуны үзенчә кичерде [Татар теленең язма корпусы] (Lyubasha, whose face was as pink as the shade of dawn and as white as sugar, endured the divorce in her own way [Corpus of Written Tatar]);

Хәзрәт мамык кебек ак, йомшак кулларын биреп саубуллашты да жсир өстендә йөзгән томан кебек, салмак кына атлап китеп барды [Tатар теленең язма корпусы] (Khazret said goodbye, shaking with his fluffy white hands, and slowly sweeping across the ground like fog [Corpus of Written Tatar]);

Көзгегә караганчы ук мин кулларымның сабыйларныкы кебек ак һәм жсыерчыксыз булуын күрәм [Татар теленең язма корпусы] (Even without peering in the mirror, I could see that my hands were white and without wrinkles, like babies' [Corpus of Written Tatar]);

Вәгъдәгөл карчыкны күргәч, Вера гажсуәпләнеп куйды: башы кар кебек ак, ник ичмасам бер кара чәче күренсен [Татар теленең язма корпусы] (Vera was surprised to see the old woman Vagdagul, whose hair was as white as snow, not a single black hair could be seen [Corpus of Written Tatar]);

Хәтта шәһәребезнең атаклы галиме, тарих фәннәре докторы Вәли ага үзе дә, куллары белән кар кебек ак чигаләрен кысыли, бүлмәдә әрле-бирле йөрена һәм сөйлана иде...[ Письменный корпус татарского языка] (Even Vali aga himself, a famous scientist, doctor of History, walked up and down the room, hands clutching his temples as white as snow and talking... [Corpus of Written Tatar]);

Картның сөт кебек ак сакалы калтыранып китте [Татар теленең язма корпусы] (The old man's beard, as white as milk, quivered [Corpus of Written Tatar]);

Юк, ятим булмас аның әтисе кебек үк киң маңгайлы, зур кара күзле, кызлар кебек ак йөзле, озын керфекле уль [Татар теленең язма кopnycbl] (No, his son with a wide forehead, same as his father's, and big black eyes, with long girllike eyelashes and a white face, will never be an orphan [Corpus of Written Tatar]);

Тәне шилкан кебек ак һәм тылыз, жсилкәләре киң иде Гафурның [Татар теленең язма корпусы] (Gafur's body was white and dense, like a turnip, and his shoulders were broad [Corpus of Written Tatar]).

In the previous examples, images of snow, milk, sugar, cotton, baby, etc. have a positive connotation. These standards coincide with the definitions given in the dictionaries.

Менә мин нишлим, мена ник битем киндер кебек ак, мена ник минем күзләрем тиле кешенеке кебек! [Татар теленең язма корпусы] (What should I do?! My face is as white as canvas, and my eyes are like those of a stupid person! [Corpus of Written Tatar];

Нәрсә булды, йөзең чүпрәк кебек ак? - диде аңа тегесе [Татар теленең язма корпусы] (What's happened, you have turned pale (your face has become as white as a rag)? - he said [Corpus of Written Tatar]).

In these comparisons, white is also used, but through the images of canvas and rags, so a person's appearance is negatively assessed.

White has a strong emotional impact on human consciousness, because it creates associations with light, day and purity. All these examples prove that white is used for a positive characterization. Therefore, due to the "white" component these comparisons are used to describe the purity of the human soul and to characterize a person positively. For example:

Шул мизгелда сине жсира төшереп, теге Хозыр Ильяс кебек ак Бабай, елмаймыгйнитми, китаплар артыннан килеп чыла һәм синең кульцңа озынлыгы ике метрдан да ким булмаган очлы таяк тоттыра [Татар теленең язма корnyсbl] (At this moment, as if bringing you to your senses, a white Old Man, reminiscent of the prophet Ilyas, appears from behind the bookshelves and holds out a stick at least two meters long. [Corpus of Written Tatar]);

Зөбдйда - кар кебек ак, су кебек пакь кыз [Татар теленең язма корпусы] (Zubeida is as white as snow, a girl, as pure as water [Corpus of Written Tatar]); 
Ул да бүген нәкъ шул каен кебек ак иде, биек иде һам бахетле иде, кичаге көнне кичдгесенда калдырып, бүген чиксез бахетле иде [Tатар теленен язма корпусы] (Today she was just as happy, tall and as white as a birch, leaving yesterday behind, today she was immensely happy [Corpus of Written Tatar]).

In the Tatar language, the word "white" in combination with the words ash and oil in one phrase creates a certain image. For example:

Кадермәтнең йөзе көл кебек ак, иреннәре күгәреп каткан...[Татар теленең язма кopnycbl] (Kadermet was as pale as ash, and his lips turned blue ... [Corpus of Written Tatar]);

Йомарлак май кебек ак тезлорен капларкапламас чуар күлмәк...[Татар теленең язма корnycul] (Dress barely covering her knees as white as butter [Corpus of Written Tatar]).

In these comparisons a person's features can acquire both positive and negative connotations, depending on the context.

In the Russian language, comparisons with the "white" component are often used when depicting one's body, face, hair, beard, etc. In the Explanatory Dictionary of the Russian Language, white is used in comparisons with something snowy and chalky. Therefore, as an object of comparison, the images of snow, chalk, paper, cotton, milk, flour, birch, etc. are also widespread. For example:

Его атласные волосы, белые, как снег, были расчесаны; он разглаживал седую бороду [Национальный корпус русского языка] (His silky hair, as white as snow, was combed; he was smoothing his gray beard [Russian National Corpus]);

Подошёл Василий совсем близко: лица на нём нету, белый, как мел, глаза дикие; говорить начал - голос обрывается [Национальный корпус русского языка] (Vasily came very close: his face was as white as chalk, his eyes were wild; when he began to speak - his voice broke off [Russian National Corpus]);

Нюрка стала реветь без слов, а Володя, белый как бумага, лепетал и точно боролся с кем-то, кто подшибал его под коленки, опрокидывал навзничь и душил [Национальный корпус русского языка] (Nyurka began to wеep without saying a word, and Volodya, as white as paper, was babbling and definitely fighting someone who kicked him under his knees, knocked him over and was strangling [Russian National Corpus]);
Оксана обернулась - брат был с лица белый как простыня и белой же рукой указывал на что-то там, на земле [Национальный корпус русского языка] (Oksana turned around - her brother's face was as white as a sheet and with his white hand he was pointing at something on the ground [Russian National Corpus]);

Номер вполне мог стать смертельным, $u$ Виталий действительно на миг потерял сознание, но все же опомнился и, белый, как полотно, самоотверженно довел до кониа эпизод с канарейкой [Начиональный корпус русского языка] (The act could well have become fatal, and Vitaly really lost consciousness for a moment, but nevertheless came to his senses and, as white as a sheet, selflessly completed the episode with the canary [Russian National Corpus]);

Бросила взгляд на Рапопорта - он белый как скатерть [Начиональный корпус русского языка] (I glanced at Rapoport - he was as white as a tablecloth [Russian National Corpus]).

In Russian, the words harrier, deceased, death, etc. are more often used to create special images. For example:

Седые волосы, белье как лунь, бритое лищо - некрасивое, но интересное каждою морщинкой [Национальный корпус русского языка] (His gray hair was as white as a harrier, his shaved face was ugly, but interesting with its every wrinkle [Russian National Corpus]);

Фомич сидел посреди дороги, белый как покойник, и еле дышал, убитый жарой [Начиональный корпус русского языка] (Fomich was sitting in the middle of the road, as white as a dead man, and could hardly breathe because of heat [Russian National Corpus]);

Хмель из плотника вышибло, а рядом, белый, как смерть, стоял шофер [Национальный корпус русского языка] (The carpenter immediately sobered up, and next to him, as white as death, was the chauffeur [Russian National Corpus]).

In Russian, the whiteness of a person's face is associated with death, through the images of death and the deceased not only the appearance of a person is described, but also his/her physical condition and internal worries.

Obviously, both languages have similar lexical-thematic groups of images as these examples show. Comparisons with a "white" component in Tatar and Russian are used to describe human hair (gray hair), teeth, complexion, 
as well as one's physical and emotional state (illness, fatigue, anxiety, fear, etc.).

Black color

KAPA (KARA)

\begin{tabular}{|l|l|}
\hline 1) Корым төсендәге; иң & $\begin{array}{l}\text { 1) Ash color; the darkest } \\
\text { караңгы төсле. }\end{array}$ \\
color.
\end{tabular}

2) Куерак, караңгырак 2) Thick, darker color. төстәге.

3) Караңгы; яктылык төшми торган, куе, калын.

4) Негроид расаның билгесе буларак, ак тәнлеләрдән нык аерылган караңгы төстәге.

5) Тумыштан каратутлы, чәче həм тән төсе башкаларныкыннан караңгырак булган.

6) Кояш астында озак булудан, жылы якларда яшәүдән аклыгын югалткан, каралган, кояшта кызган (кешедә бит, тән төсе тур.).

7) Керле, пычрак, юынмаган.

8) Сөт кушылмаган (чәй, кофе h.б.ш.).

9) иск. Махсус

исерткеч итеп эшләнә торган (кымыз).

10) Моржасыз, төтене махсус тишектән төнлектән чыга торган (мунча, өй тур.).

11) иск. Хезмәтчеләр тора торган, кышын терлек-туар кертелә торган (өй, бүлмә тур.) [Татар теленең аңлатмалы сүзлеге].

3) Dark; a place where no light falls.

4) As a sign of the Negroid race, distinguishing it from the white-skinned.

5) Dark by nature, hair and skin color, darker than others.

6) The one who has lost whiteness because of a long stay in the sun, life in warm regions (human face, skin color).

7) Dirty, not washed.

8) Without milk (tea, coffee, etc.).

9) Outdated: Made specifically to treat intoxication (koumiss). 10) Without a chimney (sauna, home tour).

11) Outdated: A place to live for workers in the summer and livestock in the winter (about a house, a room).

[Explanatory Dictionary of the Tatar Language].

ЧЁРНЫЙ (CHERNIY), -ая, -ое; чёрен, черна, черно и чёрно.

\begin{tabular}{|l|l|}
\hline 1. Цвета сажи, угля. & 1. Colors of soot, coal. \\
2. полн. Тёмный, в & 2. Full m. Dark \\
противоп. чему-н. & contrasted to something \\
более светлому, & lighter called white. \\
именуемому белым. & \\
3. Принявший тёмную & 3. The one accepting \\
\hline
\end{tabular}

окраску, потемневший. 4. полн. В старину: то же, что курной. Чёрная баня.

5. перен. Мрачный, безотрадный, тяжёлый.

6. полн., перен.

Преступный, злостный. 7. полн. Не главный, задний (о входе, ходе).

8. полн. О труде: физически тяжёлый и неквалифицированный. 9. полн.

Принадлежащий к непривилегированным, эксплуатируемым классам общества (устар.).

10. полн. На Руси в 1217 вв.:

государственный, не частновладельческий.

11. полн. С тёмной кожей (как признак расы), чернокожий [Толковый словарь Ожегова].

dark color, darkened. 4. Full $\mathrm{m}$. In the old days: the same as a house heated by a stove without a chimney. A black bath. 5. Fig. m. (figurative meaning). Gloomy, bleak, heavy.

6. Fig. m. Criminal, malicious.

7. Not the main one, the back one (about an entrance, a passage).

8. Full $m$. About work: physically difficult and unskilled.

9. Full $\mathrm{m}$. Belonging to the underprivileged, exploited classes of society (obsolete).

10. Full $m$. In Russia in 1217 centuries:

belonging to the state, not private.

11. Full $m$. With dark skin (as a sign of race), black-skinned [Ozhegov's Explanatory Dictionary].

Since ancient times, people have associated black with nights and darkness. This color in the human mind is associated with danger. Therefore, comparisons that include this color are actively used to create negative images in both languages. For example:

Чырайлары корым сарган кебек кара көйгән [Татар теленең язма корпусы] (Their faces are as black as soot [Corpus of Written Tatar])

Берни дә барып чыкмагач, шайтан кебек кара йөзле, сасы сарымсак белән тәмәке исе аңякытып торган урыс аны этә-төртә урамга куыл чыгарды [Татар теленен язма корпусы] (When nothing came of it, a Russian, as dark as the devil, smelling of garlic and tobacco, pushed him out into the street [Corpus of Written Tatar]);

Аннан таза гәүддле, сумала кебек кара чырайлы, кысык күзле, чәче-кашы ат кылын хәтерләткән аддм күренде [Татар теленен язма корnусы] (From there appeared a stocky man with his face as black as pitch, with narrow 
eyes, hair and eyebrows, reminiscent of a horse's mane [Corpus of Written Tatar]);

Чырайлары чытылк, битлоре кайрак кебек кара янган [Татар теленең язма корпусы] (Their faces were wrinkled and as black as emery [Corpus of Written Tatar]);

Совсем как этот: усатый, черный, как головешка, со зльм лииом [Наџиональный корпус русского языка] (Just like this one: moustached, as black as a firebrand, with an evil face [Russian National Corpus]);

Иногда приходил черный как туча, вздрагивал от каждого шороха [Национальный корпус русского языка] (Sometimes he came as black as a black cloud, flinching at every rustle [Russian National Corpus]);

В иентре группь на охапке сена возлежал черный, как негр, детина $c$ одной ногой [Национальный корпус русского языка] (In the center of the group, on an armful of hay, was reclining a big one-legged man, as black as a Negro [Russian National Corpus]);

Apan лежал в гробу в морском мундире времени Екатерины, черный как уголь... [Национальный корпус русского языка] (The blackamoor lay in a coffin in a naval uniform of Catherine's time, and he was as black as coal ... [Russian National Corpus]);

Comparisons with this color can be found in the descriptions of hair, eyes and eyelashes in both languages. The following words are actively used in set phrases: night, resin, coal, earth, cloud, bird cherry, currant, raven, raven wings, Arab, gypsy, etc. For example:

Күзләре минекенд охшаган, төн кебек кара [Татар теленең язма корпусы] (Eyes like mine, as black as night [Corpus of Written Tatar]);

Чигә чәчең кара иде, / Сумала кебек кара [Tатар теленең язма корпусы] (Your hair was black, / as black as resin [Corpus of Written Tatar]);

Алланып торган кояш чыгышыннан китерелгән жситез егетнең шомырт кебек кара күзләренә кылдан нечкә итеп очланган инәләр кададылар, ди [Татар теленең язма кopnycbl]( A lively guy rose with the first rays of the dawn, his eyes as black as bird cherries as if pierced by very sharp needles, thinner than a string [Corpus of Written Tatar]);

Ул арада сигез-ун яшьлек яланаяк, яланбаш, Үзләре ком гарәбе кебек кара янган ике малай килеп чьктыь [Татар теленең язма корпусы] (Meanwhile, two boys, about eight or ten years old, appeared, barefoot, bareheaded and burnt out in the sun, both as black as guides in the desert [Corpus of Written Tatar]);

Чегән кебек кара чәчле, кара тәнле булганы өчен гена түгел, а эмчеләр арасында иң яме булганга да, аңза шулай дип дәшәләр иде [Tатар теленең язма корпусы] (That was his name not only because he was black-haired, like a gypsy, but also because he was the youngest among the workers [Corpus of Written Tatar]);

Телефон баганасыдай озын, мунча ташы кебек кара Хәниф иде ул [Татар теленең язма кopnycbl] (Hanif was as long as a telegraph pole, as black as a bath stone [Corpus of Written Tatar]);

Икенчесе егерме-егерме бим яшьлардаге егет, ә яңакларында кара урман кебек кара сакал [Татар теленең язма корпусы] (The second young man was in his twenties, and on his cheeks he had a beard as black as a thick forest [Corpus of Written Tatar]);

Төн кебек кара, ишелеп төшкән чәчләрен төзәтеп куйды [Татар теленең язма корпусы] (He straightened his hair as black as night [Corpus of Written Tatar]);

Күмер кебек кара чәчләре арасында көмешсу көл сибелгән кебек [Татар теленең, язма корпусы] (It seemed that his hair, as black as coal, was sprinkled with silvery ash [Corpus of Written Tatar]);

Аннан кальин гына гәүдәле, туль битле, кысыграк күзле бер кеше төште, кашы, иәчлоре сумала кебек кара [Татар теленең язма корnyсbl] (A fat, plump-faced man with narrow eyes, pitch-black eyebrows and hair descended from there [Corpus of Written Tatar]).

In the Russian language, the same images are actively used. For example:

Лица их были смуглые, носы приплюснутые и губы толстые, глаза чёрные, как смоль, равно как и волосы, висящие прядями, иные были с редкими бородами, иные же и вовсе без бород; в разные части лица были у них воткнуты длинные косточки и вставлень камешки [Начиональный корпус русского языка] (Their faces were swarthy, their noses were flattened and their lips were thick, their eyes were pitch-black, as well as their hair hanging in strands, some wore sparse beards, others without beards at all; they had long bones and pebbles stuck in different parts of their faces [Russian National Corpus]);

И я, подчиняясь моему порыву, наклонилась $\kappa$ ней и нежно почеловала ее глаза, черные, как ночь, и горящие, как алмазы [Наџиональный 
корпус русского языка] (And I, obeying my impulse, bent down to her and tenderly kissed her eyes, as black as night and as shiny as diamonds [Russian National Corpus]);

Передок занимал квадратный, черный как ворон мужник... [Национальный корпус русского языка] (The front end was occupied by a squareshaped man, as black as a raven ... [Russian National Corpus]);

Лицо у него было смуглое, два черных глаза горели, как угли, не покрытые париком короткие волосы, черные, как воронье крыло, вились мелкими кольцами, и весь он был одет в черное [Национальный корпус русского языка] (His face was swarthy, his two black eyes shone like coals, his short hair was not covered with a wig, it was as black as a crow's wing, curled in small rings, and he was all dressed in black [Russian National Corpus]);

Лёва высокий, стройный, чёрный, как цыган, Олеся ему по плечо, белоличая русалоч$\kappa a$ с льняными волосами... [Начиональный корпус русского языка] (Lyova is tall, slender and as black as a gypsy, Olesya is shorter, a whitefaced mermaid with flaxen hair ... [Russian National Corpus]).

With the help of this color, both a positive and negative image can be created, depending on the ratio of the object and the image.

When describing a person's appearance (hair, eyes, eyebrows, eyelashes), black often makes a positive impression, it creates a negative image when depicting people's physical condition or their inner experiences.

Red color

КЫЗЫЛ (KYZYL)

\begin{tabular}{|l|l|}
\hline 1) Спектрның төп & 1) the color of blood, the \\
төсләреннән иң & color of the very first of \\
беренчесе төсле, кан & the primary colors of the \\
төсендәге. & Spectrum. \\
2) сөйл. Йоны, төкләре & 2) colloquial: Wool, hair \\
кызгылт көрән, куе & is red-brown, with a \\
жирән төсле (сыер, & dark red color (about the \\
бозау төсе тур.). & color of cows, calves). \\
3) Кызыл төс алган, & 3) turned red, blushed \\
беркадәр кан төсе & somewhat. \\
кергән, кызарган. & \\
4) тар. Октябрь & 4) narrow meaning: \\
революциясенә, & Related to the October \\
революциядә & Revolution, participants \\
катнашучыларга, & in the revolution, the \\
большевикларга, & Bolsheviks, \\
революцион & revolutionary activities; \\
эшчәнлеккә & belonging to the Soviet \\
\hline
\end{tabular}

\begin{tabular}{|l|l|}
\hline бәйләнешле; Советлар & Union, the Red Army. \\
Союзына, Кызыл & \\
Армиягә караган. & \\
Жәдк. тар. & 5) outdated, narrow \\
хәрәкәтендә & meaning: A member of \\
катнашучы, & the Jadid movement in \\
жәдитчелек тарафында & Jadidism. \\
булган. & \\
6) күч. Һич & \\
тайпылмыйча билгеле & 6) figurative meaning: \\
бер карашны яклаучы, & Orthodox, resistant \\
эзлекле тарафдар & follower of a particular \\
булган, ортодокс & point of view. \\
булган. & \\
7) Ботаника, зоология, & \\
минералогия кебек & 7) used as the first \\
фәннәрдәге кайбер & component of some \\
тезмә терминнарның & combination terms in \\
беренче компоненты & such sciences as botany, \\
буларак кулланыла. & zoology, mineralogy. \\
8) Югары пробалы, саф & \\
(кыйммәтле металлар & 8) the highest standard, \\
тур.). & pure (about precious \\
9) Югары уку йортын & metals). \\
“бик яхшы” билгеләре & 9) referred to university \\
белән генә тәмамлаган & graduates who \\
студентларга бирелә & graduated with honors \\
торган (диплом тур.) & (about a diploma). \\
[Татар теленең & [Expressive Dictionary \\
аңлатмалы сүзлеге]. & of the Tatar Language]. \\
\hline
\end{tabular}

КРÁСНЫЙ (KRASNIY), -ая, -ое; -сен, -сна, сно и -сно.

\begin{tabular}{|c|c|}
\hline $\begin{array}{l}\text { 1. (-сно). Цвета крови, } \\
\text { спелых ягод } \\
\text { земляники, яркого } \\
\text { цветка мака. } \\
\text { 2. полн. Относящийся } \\
\text { к революционной } \\
\text { деятельности, к } \\
\text { советскому строю, к } \\
\text { Красной Армии. } \\
\text { 3. Употр. в народной } \\
\text { речи и поэзии для } \\
\text { обозначения чего-н. } \\
\text { хорошего, яркого, } \\
\text { светлого. } \\
4 . \text { полн. Употр. для } \\
\text { обозначения наиболее } \\
\text { ценных пород, сортов } \\
\text { чего-н. (спец.). }\end{array}$ & $\begin{array}{l}\text { 1. The colors of blood, } \\
\text { ripe strawberries, bright } \\
\text { poppy flowers. } \\
\text { 2. Full m. Related to } \\
\text { revolutionary activities, } \\
\text { to the Soviet system, to } \\
\text { the Red Army. } \\
\text { 3. Used in folk speech } \\
\text { and poetry to denote } \\
\text { something good, bright, } \\
\text { beautiful. } \\
\text { 4. Full m. Used to } \\
\text { designate the most } \\
\text { valuable breeds, } \\
\text { varieties of something. } \\
\text { (specialist.). } \\
\text { 5. Supporter or }\end{array}$ \\
\hline
\end{tabular}




\begin{tabular}{|l|l|}
\hline Сторонник или & representative of the \\
представитель & Bolsheviks, their \\
большевиков, их & revolutionary \\
революционной & dictatorship, a soldier of \\
диктатуры, & the Red Army \\
военнослужащий & [Ozhegov's Explanatory \\
Красной Армии & Dictionary]. \\
[Толковый словарь & \\
Ожегова]. & \\
\hline
\end{tabular}

Red is distinguished by its brightness and beauty among other colors, this color has many figurative meanings. For many peoples, it is a sacred color, often associated with blood and fire.

In red component comparisons, we find the names of garden and field flowers, berries, fruit and vegetables. For example:

Оятыннан гөл кебек кызыл йөзе, Ак киемнән, алтын тажс кигән үзе [Татар теленең язма корпусы] (His face was as red as a flower, and he was wearing white clothes and a golden crown [Corpus of Written Tatar]);

Кырысрак сыман күренгән хатын бала янында бөтенлай эреде, ул аны иркәли, алма кебек кызыл битләреннән Үбә башлады [Tатар теленең язма корпусы] (The woman, who looked stricter, changed completely when having the child around, she was caressing him, kissing him on the cheeks as red as apples [Corpus of Written Tatar]);

Ә анда, авызын ерып, жңиләк кебек кызыл чырайлы Әнвәр абый бүрәнә юнып маташа иде [Татар теленен язма корпусы] (And there, with a face as red as a berry, Anvar aby, smiling broadly, was hewning a log [Corpus of Written Tatar]);

Кызый чибәр, аның карлыгандай кара күзләренд, чия төсле кызыл иреннәрено, алма кебек тыгыз, түгәрәк күкрәкләрена сокланып карап тормыйча түзеп булмый [Tатар теленең язма корпусы] (The girl is beautiful, it is impossible to avoid looking into her eyes as black as currants, lips as red as cherries, and breasts as lush as apples. [Corpus of Written Tatar]);

Йөзе чөгендер кебек кызыл иде [Татар теленең язма корпусы] (The face was as red as beetroot [Corpus of Written Tatar]).

In Russian, in comparisons related to this group, there are often names of animals and fiery images in addition to the names of flowers, fruit and vegetables; this color has much more metaphorical meanings. For example:

Красный, как пион, Соткин смотрел в холодное лицо унтера едва не умоляющими глазами [Наџиональный корпус русского языка] (Red as a peony, Sotkin gazed into the sergeant's cold face with almost pleading eyes [Russian National Corpus]);

Быстро исчезнет с него тогда человеческий облик: обрюзглая, посиневшая физиономия, губы красные, как огонь, и мутные глаза выразят в телесных формах неутолимую тоску его души [Национальньй корпус русского языка] (Then his human appearance will quickly disappear: his flabby, blue face, his lips as red as fire, and dull eyes will express the unquenchable melancholy of his soul in bodily forms [Russian National Corpus]);

Какой он сидел тогда красный, как помидор спельй, как из города Омского явился, думал я, ему веку не будет...[ Национальньй корпус русского языка] (He was red, like a ripe tomato, as if he came from the city of Omsk, I thought, he wouldn't last long... [Russian National Corpus]);

Он смутился и стал красный, как свекла [Национальный корпус русского языка] (Не was embarrassed and turned red as beetroot [Russian National Corpus]);

Несколько справившись с собою, весь красный как рак, он объявил, что счёл долгом поднять рубашечку, лично принести её... [Национальный корпус русского языка] (Having calmed down a little, all red as a crawfish, he announced that he considered it his duty to pick up the shirt and personally bring it ... [Russian National Corpus]);

Подкосились снова ноженьки у Наташи, а Василий уже идет к ней, идет - весь красный, как огонь, от крови, глаза горят у него, как костры в темной ночи, - и он к ней руки тянет [Начиональный корпус русского языка] (Natasha's legs yielded, and Vasily was already walking towards her, walking - all as red as fire with blood, his eyes burning like bonfires in a dark night - and he was reaching out to her [Russian National Corpus]);

А только что он был красный, как пожар [Национальный корпус русского языка] (And just before it he was as red as fire [Russian National Corpus]).

Comparisons in this group create a positive image when describing people's lips, eyes, nose and complexion, reflecting the physical or spiritual state of a person, and, on the contrary, they can be used to show the negative attitude of the writer or storyteller. 
Green color ЯШЕЛ (YASHEL')

\begin{tabular}{|l|l|}
\hline 1. Спектрда төп & 1. One of the primary \\
төсләрнең берсе - & colors in the spectrum is \\
зәңгәр белән сары & a color between blue and \\
арасындагы төс; үлән, & yellow; the color of \\
үсемлек, яфрак төсе. & herbs, plants, leaves. \\
2. Үлән үскән, яшеллек & 2. Covered with \\
каплаган [яшел & greenery or grass [a \\
болын]. & green meadow]. \\
3. Үләннән, яфрактан & 3. Consisting of grass or \\
торган [яшел азык]. & leaves [green food]. \\
Ашарга яраклы & Made from the leaves of \\
үләннәрнең (кузгалак, & edible herbs (reeds, \\
кычыткан h.б.ш.) & nettles, etc.), freshly cut \\
яфрагыннан & grass [green]. \\
әзерләнгән. яңа & \\
чабылган, яңа өзелгән & \\
[яшел печән]. & \\
4. Жиләк-жимеш, & 4. Fruit and berry, grain, \\
ашлык h.б.ш. тур.: & etc.: unripe [green rye]. \\
өлгермәгән, & \\
житлекмәгән. рәв. & \\
Өлгермәгән килеш & \\
[арыш яшелрәк & \\
урылган]. & \\
5. күч. Бик яшь hәм & 5. Fig. m. Very young \\
тәжрибәсез [бераз & and inexperienced \\
яшьрәк һәм яшелрәк & [Dictionary of the Tatar \\
булса да] [Татар & Language, 2005, p. 738). \\
теленең аңлатмалы & \\
сүзлеге, 2005, б. 738]. & \\
\hline
\end{tabular}

ЗЕЛЁНЫЙ (ZELENIY), -ая, -ое; зелен, зелена, зелено, зелены и зелены.

\begin{tabular}{|l|l|}
\hline 1. Цвета травы, & 1. Colors of grass, \\
листвы. & foliage. \\
2. О цвете лица: & 2. Complexion: pale, \\
бледный, землистого & earthy shade \\
оттенка (разг.). & (colloquial). \\
3. полн. Относящийся & 3. Vegetation; consisting \\
к растительности; & of greenery. \\
состоящий, сделанный & \\
из зелени (во 2 и 3 & \\
знач.). & \\
4. О плодах: & 4. About unripe fruit \\
недозрелый [Толковый & [Ozhegov's Explanatory \\
словарь Ожегова]. & Dictionary]. \\
\hline
\end{tabular}

The "green" component comparisons are rare in the Tatar and Russian languages. In both languages, they are usually used to describe human eyes, plants, precious stones (emerald, malachite), names of animals, etc. For example:
Бу хәбарне ишеткәннан соң,, Поцелуйкин, кулларын угалап, утырган урынында сикереп куйды, мәченеке кебек яшел күзләре кечерәеп, жсыерчыклар эчендә тәмам югалып калды, томшык борыны тагын да нечкәреп киткәндәй булды [Татар теленең язма корпусы] (When Potseluikin heard this news he sprang up rubbing his hands. His green, catlike eyes were closed, it was difficult to see them among the wrinkles, and his beak-like nose looked even smaller [Corpus of Written Tatar]);

Рәбиганың ямел больннардагы күлләрнең суы төсле яшел күзлоре минем каршымда ич...[Tатар теленең язма корпусы] (Rabiga's eyes, as green as lakes in the valley, happened to be opposite mine. [Corpus of Written Tatar]);

Мена ни төсле икән аның күзләре! Малахит ташы төсле яшел [Татар теленең язма корпусы] (That's the colour of her eyes! The green colour of malachite [Corpus of Written Tatar]);

Ул сарыктан кеше ясаудан ләззәт таба, ә син аның белән яндшә булудан, аның ж⿻әй төсле яшел күзләренд рәхәтлек кичерәсец [Tатар теленен язма корпусы] (Hе enjoys the fact that he can fool a person, and you enjoy looking into his eyes as green as summer. [Corpus of Written Tatar]);

У них были совершенно одинаковые глаза зеленые, как крыжовины, в светлых ресницах [Национальный корпус русского языка] (Тhеу had exactly the same eyes - as green as gooseberries, with pale eyelashes [Russian National Corpus]);

Увидел, что она мулатка, что плечи у нее мягкие и округлье, а глаза зеленые, как у кошки [Национальный корпус русского языка] (I saw that she was a mulatto, that her shoulders were soft and round-shaped, and her eyes were as green as cats' [Russian National Corpus]);

Льсый безрукий верзила. Глаза зеленые, как трава [Начиональный корпус русского языка] (Bald, armless bruiser. His eyes were as green as grass [Russian National Corpus]);

- Только нос немножко широк да глаза зеленые, как у ящерицы [Национальный корпус русского языка] (- Only the nose is a little too wide and his eyes are as green as lizards' [Russian National Corpus]).

In most comparisons, green eyes produce a positive impression, in images with a negative connotation, on the contrary, the appearance of a person and his inner world are shown in a disagreeable way. 
Blue color

Зәңгәр (Zangar)

\begin{tabular}{|c|c|}
\hline $\begin{array}{l}\text { 1. 1) Спектрда яшел } \\
\text { белән күк арасындагы } \\
\text { төп төсләрнең берсе - } \\
\text { күк йөзенең аяз } \\
\text { көндәге ачык төсе, } \\
\text { диңгез төсе. } \\
\text { 2) күч. Ачы, югары } \\
\text { тондагы; көчле, } \\
\text { чәрелдәп торган. } \\
\text { 2. и. мәгъ. 1) Зәңгәр } \\
\text { төс, зәңгәр буяу [Татар } \\
\text { теленең аңлатмалы } \\
\text { сүзлеге]. }\end{array}$ & $\begin{array}{l}\text { 1. One of the main } \\
\text { colors between green } \\
\text { and violet in the } \\
\text { spectrum; the color of } \\
\text { the clear sky, the color } \\
\text { of the sea. } \\
\text { 2) Fig. m.: a nasty, high } \\
\text { tone; strong, shrill. } \\
\text { 2. Blue color, blue paint } \\
\text { [Explanatory Dictionary } \\
\text { of the Tatar Language]. }\end{array}$ \\
\hline
\end{tabular}

СИ́НИЙ (SINIY), -яя, -ее; синь, синя, сине.

\begin{tabular}{|c|c|}
\hline $\begin{array}{l}\text { 1. Имеющий окраску } \\
\text { одного из основных } \\
\text { цветов спектра } \\
\text { среднего между } \\
\text { фиолетовым и } \\
\text { зелёным. } \\
\text { 2. О коже: сильно } \\
\text { побледневший, } \\
\text { приобретший оттенок } \\
\text { этого цвета [Толковый } \\
\text { словарь Ожегова]. }\end{array}$ & $\begin{array}{l}\text { 1. Having a color of one } \\
\text { of the primary colors of } \\
\text { the spectrum in the } \\
\text { middle between violet } \\
\text { and green. } \\
\text { 2. About the skin: very } \\
\text { pale, acquiring a shade } \\
\text { of this color [Ozhegov's } \\
\text { Explanatory Dictionary]. }\end{array}$ \\
\hline
\end{tabular}

In comparisons of the Tatar and Russian languages, the main function of blue is to depict the color of eyes. In addition, it is used in comparisons to reveal not only the color, but also the shape of eyes, and a person's inner experience. In both languages, it often describes sea, lake, water, air, sky, flower, field, etc. For example:

Су кебек зәңгәр күзле, жсирән чәчле, ди, Үзләре [Татар теленең язма корпусы] (They say they have water-blue eyes and red hair. [Corpus of Written Tatar]);

Төпсез күл кебек зәңгәр күзләре сөйкемле генә карый иде [Татар теленең язма корпусы] (Blue, like a bottomless lake, her eyes looked at me sweetly [Corpus of Written Tatar]);

Кыр чәчкәсе кебек зәңгәр күзле кыз! [Татар теленең язма корпусы] (A girl with eyes as blue as a wildflower! [Corpus of Written Tatar]);

Кыр чәчәге төсле зәңгәр күзләрендә борчылу [Татар теленең язма корпусы] (There was anxiety in her eyes as blue as a wildflower. [Corpus of Written Tatar]);

Ятаклар асль-өсле куелган бүлмәчеккә төшсәң, шул ук таныш йөзләргә, озынча, кыльчтай, төерчекле борынга, нәселле этнеке төсле тырпаеп торган яиса башка ябышкан колакка, табигать биргән төсен отыры Үзгәртми торган өлгергән борчактай соры, күк йөзе төсле зәңгәр күзләрга, хатын-кыз турында тәмсез мәзәк сөйләргә жсайланган чапылдык авызларга юлыгасың [Татар теленең язма кopnycbl] (If you go down to a small room covered with soot, you can meet people with sharp and long, like a blade, noses, with ears sticking out like those of a thoroughbred dog, with eyes as blue as the sky that do not fade with time, people who tell strange jokes about women. [Corpus of Written Tatar]);

Tуп-туры күзгә карап алулары, алсу битларе, матур колак яфраклары, аяз күк кебек зәңгәр күзләре, озын, бөгелеп торган керфекләре, аяк атлаулары...[Татар теленең язма корпусы] (Look straight into her eyes, at her pink cheeks, beautiful ears, her eyes are as blue as the clear sky, her eyelashes are long, curved, her steps ... [Corpus of Written Tatar]);

Халкы да матур, егетләрнең күбесе озын буйльь, калын бәдәнле, кыю карашль; кызлары елга камышылдай зифа буйль, төпсез диңгез кебек зәңгәр күзлеләр [Татар теленең язма корnyсbl] (And the people are beautiful, many guys are tall, slender built, with a confident look; their daughters are slender as reeds, with eyes as blue as a bottomless sea [Corpus of Written Tatar]);

Чөенке борынль, сипкелле, күк әчү ташы кебек зәңгәр күзле, шомырт кара чәчле кыз бу озын чәчле ирнең ушын алды, күл өсте кебек зәңгәр хәзер аның күзләре [Татар теленең язма корnycbl] (A girl with a snub nose and freckles, her eyes as blue as the sky, her hair as black as a bird cherry, left the long-haired man without a word. Now his eyes were as blue as the surface of a lake. [Corpus of Written Tatar]);

Остается летний день, шевелящий листочки, березки, белье, как облака, глаза, синие, как небо над облаками...[Начиональный корпус русского языка] (There remains a summer day, stirring leaves, birches as white as clouds, eyes as blue as the sky above the clouds ... [Russian National Corpus]);

Синие, как небо Памира, глаза Люды радостно сверкали, когда вбежала она в отдел археологии, бросила на стол две золотистые монетки и торжествующе сказала... [Национальный корпус русского языка] (Luda's eyes, as blue as the Pamir sky, sparkled with joy when she rushed into the archeology department, threw two 
gold coins on the table and triumphantly said ... [Russian National Corpus]);

Глаза у нее синие, как цветочки, и смотрела она до слез доверчиво [Национальный корпус русского языка] (Her eyes were as blue as flowers, and she gazed so trustingly one could cry [Russian National Corpus]);

Наконеи, она вздохнула и открыла синие, как фиалки, глаза [Начиональный корпус русского языка] (Finally, she sighed and opened her violet-blue eyes [Russian National Corpus]);

И синие, синие, как воды родной реки, глаза девушки туманятся теперь слезами [Национальный корпус русского языка] (The girl's eyes, which used to be blue, as blue as the waters of the native river, are now full of tears [Russian National Corpus]);

На щеках румянеи, что маков ивет. Глаза игривые, синие, как тропическое море [Национальный корпус русского языка] (Her cheeks blush like poppies. The eyes are playful and as blue as a tropical sea [Russian National Corpus]).

In Russian, in addition to the images mentioned above, there are often deadly images that are frequently used to describe lips and emphasize a person's inner emotions.

За окном еще темно, а внутри вагона от тусклых лампочек у всех лица синие, как у утопленников [Национальный корпус русского языка] (It is still dark outside the window, and inside the carriage, because of the dim lights, everyone's faces are blue, like those of drowned men [Russian National Corpus]);

Однажды я подплыл к нему, с тревогой взглянул в белое, покачивающееся на воде лицо: шевельнулись синие, как у мертвеца, губы [Национальный корпус русского языка] (Опсе I swam up to him, looked anxiously at the white face swaying in the water: lips, blue, like those of a dead man, moved [Russian National Corpus]).

\section{Conclusion}

Our analysis of stable comparisons with a color component, which are often used in the Tatar and Russian languages, has led to the following conclusions.

The study shows that these comparisons, used as a means of describing and assessing the appearance and internal state of a person, are frequently found in the Tatar and Russian languages. Their active use in speech and their variety can be explained by the fact that in the environment of a person there are many objects of various colour.
In both languages, the most common colours used in comparisons are white and black. The white color reflects not only a person's appearance (hair, face, skin colour), but also the state of his/her mind (fear, anxiety, illness, etc.). In the Tatar language, this color is often used to describe purity.

Black is used to depict the color of hair, eyes, eyebrows and eyelashes. Since people with black eyes and black hair are often found among the Tatars, more comparisons with black are found in the Tatar language.

Blue and green are more common when depicting the color of eyes, less often they are used to describe lips, hands and feet, in order to show the inner experiences of a person.

The red component comparisons are used to describe the color, fullness and beauty of lips. In Russian comparisons, this color is found more often, since it is synonymous with "red" in the meaning "beautiful". The use of this color to describe noses, eyes, arms and legs emphasizes the negative attitude of the writer, or speaker.

Thus, when analyzing comparisons, firstly, the information about the object of comparison is given; secondly, the object or concept that is the standard for comparison is described. The feature, taken as the basis, is clearly expressed in the object of the comparison, therefore this sign is one of its characteristic features. The use of such comparisons in text or speech, on the one hand, names the color of the described object; on the other hand, this comparison is a signal of a positive / negative physical or psychological state of a person. The color of the ethyalon not only reveals the appearance, the color, describing a person, but also provides additional information.

Stable comparisons are a reliable object for studying the world linguistic image and a productive source for linguocultural studies, which reflect the worldview of the population, for in order to portray unfamiliar things, people almost always put it next to a similar object. Sometimes internal similarity also becomes the basis for comparison, that is, according to external features, two completely different objects or concepts coincide. It should be noted that almost always when comparing, a subjective assessment is given, a certain attitude is reflected, fixed in a language unit and an object comparable to it.

In many ways, a comparison creates a certain type of a person's image and situations.

Comparisons in the Tatar and Russian languages are characterized by similarities in the 
lexical-thematic groups of images used to describe the external appearance of a person, which is explained by the universality of human nature and human thinking and, in turn, means that the understanding of the surrounding reality is described by monochromatic comparisons. The presence of specific national standards in comparisons of the two languages is associated with mythology, culture, history, literature of each nation, as well as with the individual vision of a person representing a certain nationality.

\section{References}

Gumbol'dt, W. (1985). Iazyk i filosofiia kul'tury [Language and Philosophy of Culture]. 450 p. Moscow, Progress. (In Russian)

Maslova, V. A. (2007). Homolingualis v kul'ture: Monografiia [Homolingualis in Culture: A Monograph]. 320 p. Moscow, Gnozis. (In Russian)

Natsional'nyi korpus russkogo iazyka [Russian National Corpus]. URL: https://ruscorpora.ru/new (accessed: 26.08.2021). (In Russian)
Potebnia, A. A. (1993). Mysl' i iazyk [Thought and Language]. 302 p. Kiev, SINTO. (In Russian)

Ramazanova, D. B. (2013). Leksika na tatarskom iazyke, otnosiashchaiasia $k$ cheloveku [Tatar Vocabulary Related to a Person]. P. 364. Kazan', izdatel'stvo IYALI. (In Russian)

Tatar telenең yazma korpusy [Corpus of Written Tatar]. URL: https://www.corpus.tatar (accessed: 26.08.2021). (In Russian)

Tolkovyi slovar' tatarskogo iazyka [Explanatory Dictionary of the Tatar Language]. URL: http://suzlek.antat.ru (accessed: 26.08.2021). (In Tatar)

Tolkovyi slovar' tatarskogo iazyka (2005) [Explanatory Dictionary of the Tatar Language]. P. 848. Kazan', Dom pechati. (In Russian)

Tolkovyi slovar' Ozhegova [Ozhegov's Explanatory Dictionary]. URL: https://dic.academic.ru/contents.nsf/ ogegova/ (accessed: 26.08.2021). (In Russian)

Zamaletdinov, R. R. (2004). Tatarskaia kul'tura v iazykovom otrazhenii [Tatar Culture in Linguistic Reflection]. Moscow, Gumanit. izdat. tsentr VLADOS; 239 p. Kazan', Magarif. (In Russian)

\title{
КЕШЕНЕ БӘЯЛӘУ ЧАРАСЫ БУЛАРАК “ТӨС" КОМПОНЕНТЛЫ ЧАГЫШТЫРУЛАР (ТАТАР ҺӘМ РУС ТЕЛЛӘРЕ МАТЕРИАЛЫНДА)
}

Рәмзия Марс кызы Болгарова, Казан федераль университеты, Россия, 420008, Казан ш., Кремль ур., 18 нче йорт, ramzija5@yandex.ru.

\section{Раушания Сәгъдәтжан кызы Нурмөхәммәтова,}

Казан федераль университеты, Россия, 420008, Казан ш., Кремль ур., 18 нче йорт, rsagadat@yandex.ru.

\begin{abstract}
Мәкаләдә татар hәм рус телләрендәге төс компонентлы компаратив конструкцияләр чагыштырма аспектта тикшерелә.

Әлеге тикшеренүнең максаты - төс атамасы кергән чагыштыруларны кешенең тышкы кыяфәтен тасвирлау һәм бәяләү чарасы буларак өйрәнү. Татар теленең язма корпусыннан, рус теленең милли корпусыннан алынган мисаллар тикшеренү материаллары буларак файдаланылды. Төс компонентлы чагыштырулар кешеләрнең тышкы кыяфәтендәге табигый үзенчәлекләрне яки кешенең физик яки психологик халәтендәге тышкы билгеләрне тасвирлаганда кулланыла. Әлеге образлы сурәтләү чаралары чагыштырылучы предметның һәм образның нинди булуына карап, уңай яки тискәре образ тудырырга мөмкин.

Фәнни-тикшеренү эшенең нәзари һәм гамәли әһəмияте хезмәтнең төп нәтижәләрен татар həм рус телләре лексикологиясе, лингвомәдәниятне өйрәнүгә юнәлдерелгән хезмәтләрдә файдалану мөмкинлеге белән билгеләнә.
\end{abstract}

Төп төшенчәләр: татар теле, рус теле, чагыштырулар, төс компоненты, кешенең тышкы кыяфәте.

\section{Кереш}

Кешенең әйләнә-тирә дөнья турындагы барлык күзаллаулары аның аңында формалаша həм алар күп очракта фикерләүнең ассоциатив характеры белән аңлатыла. Кеше образы гомумтел дөнья сурәтендә дә, милли дөнья 
сурәтендә дә төп образларның берсе. Шуңа күрә кешене сурәтләгән тотрыклы компаратив тел берәмлекләрен тикшерү аның телдә чагылыш тапкан образын тулысынча күз алдына китерергә ярдәм итә.

Әйтергә кирәк, кеше образы - милли дөньяны кабул итүнең бер чагылышы. Төрле мәдәният вәкилләре Үз күзаллауларына ия, дөнья турындагы мәгълүматны үзләренчә кабул итә. В. Гумбольдт фикеренчә, “төрле телләр бер үк әйбернең төрле исемнәре генә түгел, ә аларга төрлечә караш та ул" [Гумбольдт, 1985, б.154]. Шуңа күрә дөнья сурәте телдә бары тик милли-мәдәни үзенчәлекләрне исәпкә алып кына тасвирланырга мөмкин.

А.А. Потебня билгеләп үткәнчә, “сүз ярдәмендә кеше Үзенең аңында булган нәрсәләрне яңадан танып белә. Ул бер үк вакытта хаостан яңа дөнья да ижат итә һәм бу дөньяның чикләрен киңәйтү өчен үзенең көчен арттыра" [Потебня, 1993, б. 302].

Тотрыклы чагыштырулар - татар hәм рус телләрендә актив кулланыла торган берәмлекләр. Алар образлы, тәэсирле сөйләм чаралары, күпчелек очракта сөйләүченең яки язучының хис-кичерешләрен Үз эченә ала. Фразеологиянең төрле катламнарындагы кебек үк, чагыштыруларда да халыкның күпгасырлык тәжрибәсе тупланган. Шулай ук чагыштырулар мәдәни ассоциацияләр, тел һәм мәдәни тәжрибә белән дә бәйле була.

\section{Тикшерену материаллары һәм методлары}

Татар теленең язма корпусыннан, рус теленең милли корпусыннан алынган мисаллар фәнни-тикшеренү эшенең материалы булып хезмәт итте.

Әлеге корпуслардан кешене тасвирлый торган төс компонентлы чагыштырулар кергән мисаллар тупланды, ике телдә дә иң еш кулланылучы кебек, как, шулай ук төс белән турыдан-туры бәйле төсле бәйләүче чаралары ярдәмендә төзелгән чагыштырулар тикшерелде.

Мәкаләдә фактик материалны анализлаганда, күзәтү, чагыштырма, тасвирлама һәм семантик анализ методлары кулланылды.

\section{Фикер алышу}

Кешенең тышкы кыяфәте буенча билгеле бер күләмдә мәгълүмат алырга, аның милләтен, женесен, яшен, шулай ук шәхси үзенчәлекләрен билгеләргә мөмкин. Гомумән, кешенең тышкы кыяфәте, аларны сурәтләү үзенчәлекләре милли мәдәният турында да күп нәрсә сөйли. Гадәттә, кешене тасвирлаган вакытта һәрвакытта да уңай һәм тискәре бәяләмәләр кулланыла. Әлеге хезмәттә татар hәм рус телләрендәге “төс" компонентлы чагыштырулар кешенең тышкы кыяфәтен тасвирлау һәм бәяләү чарасы буларак анализланды.

Төсләр, кешенең тышкы кыяфәте һәм эчке дөньясы үзенчәлекләренә өстәмә характеристика бирү максатында, билгеле бер объект яки күренеш белән чагыштыруның нигезен тәшкил итә. Төрле мәдәният вәкилләре бер үк төсне, аларның әһәмиятенә карап, төрлечә кабул итә һәм бәяли.

Төсләр символикасы белән кеше аңы катламнары, халыкның тарихы, мәдәни-ижтимагый тормышы арасында тирән бәйләнеш бар. Төсләр төрле мәгънәләр белдерергә, төрле хисләр уятырга һәм ассоциацияләр тудырырга сәләтле, шул рәвешле алар кешенең психик дөньясында аерым һәм үзенчәлекле үзгәрешләр барлыкка китерә. Төсләргә нисбәтле ассоциацияләр дөньяны шәхси, милли, дини h.б. кабул итү үзенчәлекләре белән бәйләнгән. Кешеләр элек-электән төсләргә аерым игътибар биргәннәр, болар халыкның ышануларында, борынгы риваятьләрдә, халык авыз ижаты әсәрләрендә, дини тәгълиматларда урын алган.

Төсләр семантикасының үзенчәлеге күпмәгънәлелектә. һәр төстә бик күп төрле мәгънәләр яшеренгән. Тотрыклы лексик берәмлекләрдә төс атамаларының нәкъ менә шул сыйфаты калкып чыга.

Фәнни тикшеренүдә татар һәм рус телләрендә тәңгәллекләре булган һәм еш кулланылган төс атамалары (татар телендә: $a \kappa$, кара, кызыл, ямел, зәңзгәр; рус телендә: бельий, черный, красный, зеленый, синий) кергән чагыштыруларга төп игътибар бирелде.

Кешелек мәдәниятендә ак hәм кара иң борынгы төсләрдән санала. Татар hәм рус телләрендәге чагыштыруларда бу төс атамалары бик еш очрый, моны әлеге төсләрнең танып-белүдәге һәм мәдәни әһәмиятенә бәйләп аңлатырга мөмкин.

Ак төс.

АК I с. 1. 1) Кар, сөт төсендәге; киресе: кара.

2) Үз төсен югалткан, чал, чаларган, көмеш төсле.

3) Ялтырап торган көмешсыман төстәге, өстеннән никель йөгерткән.

4) Борчылудан, каушаудан, авырудан йөзе үзгәргән, төсе, чырае киткән, агарынган. 
5) махс. Ике яки өч сүздән торган зоологик hәм биологик терминнарның (атамаларның) беренче кисәге.

6) күч. Чиста, керсез, пычранмаган, юылган (кием-салым турында).

7) күч. тар. Революциягә һәм Совет хөкүмәтенә каршы булган.

8) күч. Алдынгы; укымышлы, прогрессив.

9) күч. Язмыйча, буш калдырып, фикернең тәмамланмавына, яшерен эчке мәгънә булуына ишарә иткән [Татар теленең аңлатмалы сүзлеге].

БЕ́ЛЫЙ, -ая, -ое; бел, бела, бело и бело.

1. Цвета снега или мела.

2. полн. Светлый, в противоположность чему-н. более тёмному, именуемому чёрным.

3. полн. В первые годы гражданской войны: относящийся к вооружённой борьбе за восстановление законной власти в России.

4. белый, -ого, муж. То же, что белогвардеец.

5. полн. Со светлой кожей (как признак расы). Цветные и белые (сущ.) [Толковый словарь Ожегова].

Татар телендә “ак” компоненты кергән чагыштырулар кешенең тәнен, йөзен, тешләрен, кулларын, чәчләрен, сакал-мыекларын h.б. тасвирлаганда актив кулланыла. Чагыштыру объекты буларак еш кына кар, сөт, шикәр, мамык, аккош, шалкан, киндер сүзләре килә. Мәсәлән:

- Иптәшләр, ишкәкләрга ныграк басыгыз! дип пышылдый Искәндәр, һәм караңъгыда аның кар кебек ак тешләре ялтырап китәләр [Татар теленең язма корпусы];

Йөзләрена таңуның алсу төсе кунган, иикәр кебек ак йөзле Любаша аерылышуны үзенчә кичерде [Татар теленең язма корпусы];

Хәзрәт мамык кебек ак, йомшак кулларын биреп саубуллашты да жстр өстендә йөзгән томан кебек, салмак кына атлап китеп барды [Татар теленең язма корпусы];

Көзгега караганчы ук мин кулларымның сабыйларныкы кебек ак һәм жсыерчыксыз булуын күрәм [Татар теленең язма корпусы];

Вәгъддгөл карчыкны күргәч, Вера гаж⿻әпләнеп куйды: башы кар кебек ак, ник ичмасам бер кара чәче күренсен [Татар теленең язма корпусы];

Хәтта шәһәребезнең атаклы галиме, тарих фәнндре докторы Вәли ага үзе дә, куллары белән кар кебек ак чигәләрен кысыли, бүлмәда әрле-бирле йөренә һәм сөйләнә иде... [Татар теленең язма корпусы];
Картның сөт кебек ак сакалы калтыранып китте [Татар теленең язма корпусы];

Юк, ятим булмас аның әтисе кебек үк киң маңгайлы, зур кара күзле, кызлар кебек ак йөзле, озын керфекле улы [Татар теленең язма корпусы];

Тәне шиалкан кебек ак һәм тыльыз, жсилкәләре киң иде Гафурның [Татар теленең язма корпусы].

Югарыдагы мисалларда кар, сөт, шикәр, мамык, сабый h.б. образлар уңай тәэсир тудыра.Әлеге эталоннар сүзлектә бирелгән аңлатмалар белән дә туры килә.

Менд мин нишлим, менд ник битем киндер кебек ак, менд ник минем күзләрем тиле кешенеке кебек! [Татар теленең язма корпусы];

Нәрсә булды, йөзең чүпрәк кебек ак? - диде аңуа тегесе [Татар теленең язма корпусы].

Әлеге чагыштыруларда да ак төс кулланыла, тик киндер, чүпрәк образлары аша кешенең кыяфәтенә тискәре бәя бирелә.

Ак төснең кеше аңына эмоциональ тәэсире көчле, чөнки ул яктылык, көн, чисталык белән бәйле ассоциацияләр тудыра. Болар барысы да ак төснең уңай бәя бирүдә катнашуына нигез булып тора. Шуңа күрә “ак” компонентлы чагыштырулар ярдәмендә кеше күңеленең чисталыгы, сафлыгы да сурәтләнә. Бу чагыштырулар да кешегә уңай бәя бирү өчен кулланыла. Мәсәлән:

Шул мизгелда сине ж⿻ира төшереп, теге Хозыр Ильяс кебек ак Бабай, елмаймыйнитми, китаплар артыннан килеп чыла һәм синең кулыңа озынлыгы ике метрдан да ким булмаган очлы таяк тоттыра [Татар теленең язма корпусы];

Зөбдйдә - кар кебек ак, су кебек пакь кыз [Татар теленең язма корпусы];

Ул да бүген нәкъ шул каен кебек ак иде, биек иде һәм бахетле иде, кичәге көнне кичәгесенда калдырып, бүген чиксез бәхетле иде [Татар теленең язма корпусы].

Татар телендә ак сүзе, көл, май лексемалары белән бер сүзтезмәдә килеп, үзенчәлекле образ тудыруда катнаша. Мәсәлән:

Кадермәтнең йөзе көл кебек ак, иренндре күгәреп каткан... [Татар теленең язма корпусы];

Йомарлак май кебек ак тезлорен капларкапламас чуар күлмәк... [Татар теленең язма корпусы].

Бу чагыштырулар, контекстка карап, кешегә уңай бәя дә, тискәре бәя дә бирергә мөмкин. 
Рус телендә “ак” компонентлы чагыштырулар да тән, йөз, чәч, сакал һ.б.ны сурәтләгәндә еш кулланыла. Рус теленең аңлатмалы сүзлегендә дә ак төс кар, акбур төсе белән чагыштырып аңлатыла. Шуңа күрә чагыштыру объекты буларак, шулай ук кар, акбур, кәгазь, мамык, сөт, он, каен һ.б. образлары киң таралыш алган. Мәсәлән:

Его атласные волосы, белье, как снег, были расчесаны; он разглаживал седую бороду [Национальный корпус русского языка];

Подошёл Василий совсем близко: лица на нём нету, белый, как мел, глаза дикие; говорить начал - голос обрывается [Национальный корпус русского языка];

Нюрка стала реветь без слов, а Володя, белый как бумага, лепетал и точно боролся с кем-то, кто подшибал его под коленки, опрокидывал навзничь и душил [Национальный корпус русского языка];

Оксана обернулась - брат был с лица белый как простыня и белой же рукой указывал на что-то там, на земле [Национальный корпус русского языка];

Номер вполне мог стать смертельным, и Виталий действительно на миг потерял сознание, но все же опомнился и, белый, как полотно, самоотверженно довел до кониа эпизод с канарейкой [Национальный корпус русского языка];

Бросила взгляд на Рапопорта - он белый как скатерть [Национальный корпус русского языка].

Рус телендә лунь, покойник, смерть һ.б. сүзләре белән бер сүзтезмәдә кулланылып, үзенчәлекле образлар тудыру да еш очрый. Мәсәлән:

Седые волосы, белые как лунь, бритое лицо - некрасивое, но интересное каждою морщинкой [Национальный корпус русского языка];

Фомич сидел посреди дороги, белый как покойник, и еле дымал, убитый жарой [Национальный корпус русского языка];

Хмель из плотника вышибло, а рядом, белый, как смерть, стоял шофер [Национальный корпус русского языка].

Кеше йөзенең аксыллыгы рус телендә үлем белән тиңләштерелә, смерть, покойник образлары аша кешенең тышкы кыяфәте генә түгел, физик халәте дә, эчке кичерешләре дә тасвирлана.

Мисалларда ике телдә кулланылган образларның лексик-тематик төркемнәре охшаш булуы ачык күренә. Татар һәм рус телләрендә “ак” компонентлы чагыштырулар кешенең чәчләрен (чал чәчләрне), тешләрен, тән төсен, шулай ук физик һәм эмоциональ халәтен (авыру, ару, борчылу, курку һ.б.) сурәтләү өчен кулланыла.

Кара төс.

КАРА I c. 1. 1) Корым төсендәге; иң караңгы төсле.

2) Куерак, караңгырак төстәге.

3) Караңгы; яктылык төшми торган, куе, калын.

4) Негроид расаның билгесе буларак, ак тәнлеләрдән нык аерылган караңгы төстәге.

5) Тумыштан каратутлы, чәче һәм тән төсе башкаларныкыннан караңгырак булган.

6) Кояш астында озак булудан, жылы якларда яшәүдән аклыгын югалткан, каралган, кояшта кызган (кешедә бит, тән төсе тур.).

7) Керле, пычрак, юынмаган.

8) Сөт кушылмаган (чәй, кофе һ.б.ш.).

9) иск. Махсус исерткеч итеп эшләнә торган (кымыз).

10) Моржасыз, төтене махсус тишектән төнлектән чыга торган (мунча, өй тур.).

11) иск. Хезмәтчеләр тора торган, кышын терлек-туар кертелә торган (өй, бүлмә тур.) [Татар теленең аңлатмалы сүзлеге].

ЧЁРНЫЙ, -ая, -ое; чёрен, черна, черно и чёрно.

1. Цвета сажи, угля.

2. полн. Тёмный, в противоп. чему-н. более светлому, именуемому белым.

3. Принявший тёмную окраску, потемневший.

4. полн. В старину: то же, что курной. Чёрная баня.

5. перен. Мрачный, безотрадный, тяжёлый.

6. полн., перен. Преступный, злостный.

7. полн. Не главный, задний (о входе, ходе).

8. полн. О труде: физически тяжёлый и неквалифицированный.

9. полн. Принадлежащий к непривилегированным, эксплуатируемым классам общества (устар.).

10. полн. На Руси в 1217 вв.: государственный, не частновладельческий.

11. полн. С тёмной кожей (как признак расы), чернокожий [Толковый словарь Ожегова].

Элек-электән кешеләр кара төсне төн, караңгылык белән бәйләгәннәр. Бу төс кеше аңында куркыныч ассоциацияләр барлыкка китергән. Шунлыктан әлеге төс кергән чагыштырулар ике телдә дә тискәре образ тудыра. Мәсәлән: 
Чырайлары корым сарган кебек кара көйгән [Татар теленең язма корпусы];

Берни дә барып чыкмагач, шайтан кебек кара йөзле, сасы сарымсак белән тәмәке исе аңккытып торган урыс аны этә-төртә урамга куыл чызарды [Татар теленең язма корпусы];

Аннан таза гәүдәле, сумала кебек кара чырайлы, кысык күзле, чәче-кашы ат кыльын хәтерләткән адәм күренде [Татар теленең язма корпусы];

Чырайлары чытык, битлоре кайрак кебек кара янган [Татар теленең язма корпусы];

Совсем как этот: усатый, черный, как головешка, со зльмм лищом [Национальный корпус русского языка];

Иногда приходил черный как туча, вздрагивал от каждого шороха [Национальный корпус русского языка];

В иентре группь на охапке сена возлежал черный, как негр, детина $c$ одной ногой [Национальный корпус русского языка];

Apan лежал в гробу в морском мундире времени Екатерины, черный как уголь... [Национальный корпус русского языка];

Әлеге төс кергән чагыштыруларны ике телдә дә чәч, күз, каш, керфекләрне тасвирлаганда да күзәтергә мөмкин. Эталон буларак, төн, сумала, күмер, ж⿻ир, больтт, шомырт, карлыган, карга, карга канаты, гарәп, чегән h.б. сүзләр актив кулланыла. Мәсәлән:

Күзләре минекенд охшаган, төн кебек кара [Татар теленең язма корпусы];

Чигә чәчең кара иде, / Сумала кебек кара [Татар теленең язма корпусы];

Алланып торган кояш чыгышыннан китерелгән ж⿻итез егетнең иомырт кебек кара күзләрено кылдан нечкә итеп очланган инәләр кададылар, ди [Татар теленең язма корпусы];

Ул арада сигез-ун яшьлек яланаяк, яланбаш, Үзләре ком гарәбе кебек кара янган ике малай килеп чыкты [Татар теленең язма корпусы];

Чегән кебек кара чәчле, кара тәнле булганы өчен генд түгел, ә эшчеләр арасында иң яме булганга да, аңңа шулай дип дәшәләр иде [Татар теленең язма корпусы];

Телефон баганасыдай озын, мунча ташы кебек кара Хәниф иде ул [Татар теленең язма корпусы];

Икенчесе егерме-егерме биш ямьлордаге егет, д яңакларында кара урман кебек кара сакал [Татар теленең язма корпусы];

Төн кебек кара, ишелеп төшкән чәчләрен mөзәтеп куйды [Татар теленең язма корпусы];
Кумер кебек кара чәчләре арасында көмешсу көл сибелгән кебек [Татар теленең язма корпусы];

Аннан калын гына гәүдәле, тулы битле, кысыграк күзле бер кеше төште, кашы, чәчләре сумала кебек кара [Татар теленең язма корпусы].

Рус телендә дә шул ук образлар еш очрый. Мәсәлән:

Лица их были смуглые, носы приплюснутые u губы толстые, глаза чёрные, как смоль, равно как и волосы, висящие прядями, иные были с редкими бородами, иные же и вовсе без бород; в разные части лица были у них воткнуты длинные косточки и вставлены камешки [Национальный корпус русского языка];

И я, подчиняясь моему порыву, наклонилась $\kappa$ ней и нежно почеловала ее глаза, черные, как ночь, и горящие, как алмазы [Национальный корпус русского языка];

Передок занимал квадратный, черный как ворон мужик... [Национальный корпус русского языка];

Лицо у него было смуглое, два черных глаза горели, как угли, не покрытые париком короткие волосы, черные, как воронье крыло, вились мелкими кольцами, и весь он был одет $в$ черное [Национальный корпус русского языка];

Лёва высокий, стройный, чёрный, как цыган, Олеся ему по плечо, белолицая русалочка с льняными волосами... [Национальный корпус русского языка].

Әлеге төс ярдәмендә, чагыштырыла торган предметның hәм образның нинди булуына карап, уңай яки тискәре образ күзалланырга мөмкин.

Кешенең тышкы кыяфәтен тасвирлаганда (чәч, күзләр, каш, керфек), кара төс еш кына уңай тәэсир калдырса, кешенең физик халәтен яки эчке кичерешләрен сурәтләгәндә тискәре образ тудыра.

Кызыл төс.

КЫЗЫЛ I с. 1. 1) Спектрның төп төсләреннән иң беренчесе төсле, кан төсендәге.

2) сөйл. Йоны, төкләре кызгылт көрән, куе жирән төсле (сыер, бозау төсе тур.).

3) Кызыл төс алган, беркадәр кан төсе кергән, кызарган.

4) тар. Октябрь революциясенә, революциядә катнашучыларга, большевикларга, революцион эшчәнлеккә бәйләнешле; Советлар Союзына, Кызыл Армиягә караган. 
5) иск. тар. Жәдитчеләр хәрәкәтендә катнашучы, жәдитчелек тарафында булган.

6) күч. Һич тайпылмыйча билгеле бер карашны яклаучы, эзлекле тарафдар булган, ортодокс булган.

7) Ботаника, зоология, минералогия кебек фәннәрдәге кайбер тезмә терминнарның беренче компоненты буларак кулланыла.

8) Югары пробалы, саф (кыйммәтле металлар тур.).

9) Югары уку йортын «бик яхшы» билгеләре белән генә тәмамлаган студентларга бирелә торган (диплом тур.) [Татар теленең аңлатмалы сүзлеге].

КРА́СНЫЙ, -ая, -ое; -сен, -сна, -сно и -сно.

1. (-сно). Цвета крови, спелых ягод земляники, яркого цветка мака.

2. полн. Относящийся к революционной деятельности, к советскому строю, к Красной Армии.

3. Употр. в народной речи и поэзии для обозначения чего-н. хорошего, яркого, светлого.

4. полн. Употр. для обозначения наиболее ценных пород, сортов чего-н. (спец.).

5. красный, -ого, муж. Сторонник или представитель большевиков, их революционной диктатуры, военнослужащий Красной Армии [Толковый словарь Ожегова].

Кызыл төс башка төсләр арасында үзенең яктылыгы һәм матурлыгы белән аерылып тора, әлеге төснең күчерелмә мәгънәләре дә күп. Күп кенә халыкларда ул изге төс булып та санала, еш кына кан, ут төсе белән бәйләп карала.

“Кызыл” компонентлы чагыштыруларда күп очракта эталон буларак, бакча һәм кыр чәчәкләре исемнәре (мәк чәчәге, чәчәк, гөлчәчәк h.б.), жиләкләр, жиләк-жимеш, яшелчә исемнәре файдаланыла. Мәсәлән:

Оятыннан гөл кебек кызылл йөзе, $A$ к киемндн, алтын тажс кигән үзе [Татар теленең язма корпусы];

Кырысрак сыман күренгән хатын бала янында бөтенләй эреде, ул аны иркәли, алма кебек кызыл битләреннән Үбә башлады [Татар теленең язма корпусы];

Ә анда, авызын ерып, жсиләк кебек кызылл чырайлы Әнвәр абый бүрәнә юнып маташа иде [Татар теленең язма корпусы];

Кызый чибәр, аның карльгандай кара күзләренд, чия төсле кызыл иреннәрено, алма кебек тыльыз, түгәрәк күкрәкләренд сокланыл карап тормыйча түзеп булмый [Татар теленең язма корпусы];
Йөзе чөгендер кебек кызыл иде [Татар теленең язма корпусы].

Рус телендә әлеге төркемгә караган чагыштыруларда чәчәк, жиләк-жимеш, яшелчә исемнәреннән тыш, хайван исемнәре, ут-ялкын образлары да еш очрый, бу төснең метафорик мәгънәләре дә күбрәк. Мәсәлән:

Красный, как пион, Соткин смотрел в холодное лицьо унтера едва не умоляюшими глазами [Национальный корпус русского языка];

Быстро исчезнет с него тогда человеческий облик: обрюзглая, посиневшая физиономия, губы красные, как огонь, $и$ мутные глаза выразят в телесных формах неутолимую тоску его души [Национальный корпус русского языка];

Какой он сидел тогда красный, как помидор спельй, как из города Омского явился, думал я, ему веку не будет... [Национальный корпус русского языка];

Он смутился и стал красный, как свекла [Национальный корпус русского языка];

Несколько справившись с собою, весь красный как рак, он объявил, что счёл долгом поднять рубашечку, лично принести её... [Национальный корпус русского языка];

Подкосились снова ноженьки у Наташи, а Василий уже идет кней, идет - весь красный, как огонь, от крови, глаза горят у него, как костры в темной ночи, - и он к ней руки тянет [Национальный корпус русского языка];

А только что он был красный, как пожсар [Национальный корпус русского языка].

Әлеге төркемдәге чагыштырулар кешенең иреннәрен тасвирлаганда унай образ тудыра, физик яки рухи халәтен чагылдырганда, кешенең күзләрен, борынын, бит төсен сурәтләгән вакытта, киресенчә, язучының яки сөйләүченең тискәре карашын күрсәтә.

Яшел төс.

ЯШЕЛ сф.

1. Спектрда төп төсләрнең берсе - зәңгәр белән сары арасындагы төс; үлән, үсемлек, яфрак төсе.

2. Үлән үскән, яшеллек каплаган [яшел болын].

3. Үләннән, яфрактан торган [яшел азык]. Ашарга яраклы үләннәрнең (кузгалак, кычыткан h.б.ш.) яфрагыннан әзерләнгән. яңа чабылган, яңа өзелгән [яшел печән].

4. Жиләк-жимеш, ашлык һ.б.ш. тур.: өлгермәгән, житлекмәгән. рәв. Өлгермәгән килеш [арыш яшелрәк урылган]. 
5. күч. Бик яшь һәм тәжрибәсез [бераз яшьрәк һәм яшелрәк булса да] [Татар теленең аңлатмалы сүзлеге, 2005, б. 738].

ЗЕЛЁНЫЙ, -ая, -ое; зелен, зелена, зелено, зелены и зелены.

1. Цвета травы, листвы.

2. О цвете лица: бледный, землистого оттенка (разг.).

3. полн. Относящийся к растительности; состоящий, сделанный из зелени (во 2 и 3 знач.).

4. О плодах: недозрелый [Толковый словарь Ожегова].

“Яшел" компонентлы чагыштырулар татар һәм рус телләрендә күп түгел. Ике телдә дә, гадәттә, кешенең күзләрен тасвирлаганда кулланыла, образ буларак үсемлекләр, кыйммәтле ташлар (зөбәржәт, малахит), хайван исемнәре h.б. белән янәшә килә. Мәсәлән:

Бу хәбарне ишеткәнндн соң, Поцелуйкин, кулларын угалап, утырган урынында сикереп куйды, мәченеке кебек яшел күзләре кечерәеп, жсыерчыклар эчендә тәмам югальп калды, томшык борыны тагын да нечкәреп киткәндәй булды [Татар теленең язма корпусы];

Рәбиганың ямел больннардагы күлләрнең суы тосле яшел күзлоре минем каршымда ич... [Татар теленең язма корпусы];

Мена ни төсле икән аның күзләре! Малахит ташы төсле яшел [Татар теленең язма корпусы];

Ул сарыктан кеше ясаудан ләззәт таба, ә син аның белән яндшә булудан, аның жсәй төсле яшел күзләренд рәхәтлек кичерасен [Татар теленең язма корпусы];

У них были совершенно одинаковые глаза зеленые, как крыжсовины, в светльх ресницах [Национальный корпус русского языка];

Увидел, что она мулатка, что плечи у нее мягкие и округлье, а глаза зеленые, как у кошки [Национальный корпус русского языка];

Льсый безрукий верзила. Глаза зеленые, как трава [Национальный корпус русского языка];

- Только нос немножко широк да глаза зеленые, как у ящерицы [Национальный корпус русского языка].

Чагыштыруларның күбесендә яшел күзләр уңай тәэсир калдыра, образларында тискәре коннотация булганнары, киресенчә, кешенең кыяфәтен дә, эчке дөньясын да ямьсез итеп күрсәтә.

Зәңгәр төс.
ЗӘНГӘР с. 1. 1) Спектрда яшел белән күк арасындагы төп төсләрнең берсе - күк йөзенең аяз көндәге ачык төсе, диңгез төсе.

2) күч. Ачы, югары тондагы; көчле, чәрелдәп торган.

2. и. мәгъ. 1) Зәңгәр төс, зәңгәр буяу [Татар теленең аңлатмалы сүзлеге].

СЙНИЙ, -яя, -ее; синь, синя, сине.

1. Имеющий окраску одного из основных цветов спектра среднего между фиолетовым и зелёным.

2. О коже: сильно побледневший, приобретший оттенок этого цвета [Толковый словарь Ожегова].

Татар hәм рус теле чагыштыруларында зәңгәр төснең төп функциясе - күзләрнең төсенә характеристика биру. Моннан тыш, чагыштыруларда кулланылган образлар күзләрнең төсен генә түгел, күп вакытта формасын да ачыклый, кешенең эчке кичерешләренә дә ишарә итә. Ике телдә дә диңзез, күл, cy, haвa,

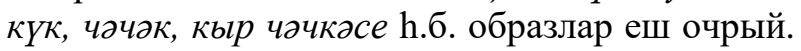
Мәсәлән:

Су кебек зәңгәр күзле, ж⿻ирән чәчле, ди, Yзләре [Татар теленең язма корпусы];

Төпсез күл кебек зәңгәр күзләре сөйкемле генә карый иде [Татар теленең язма корпусы];

Кыр чәчкәсе кебек зәңгәр күзле кыз! [Татар теленең язма корпусы];

Кыр чәчәге төсле зәңгәр күзләрендә борчылу [Татар теленең язма корпусы];

Ятаклар асль-өсле куелган бүлмәчеккә төшсәң, шул ук таныши йөзләргә, озынча, кыльчтай, төерчекле борынга, нәселле этнеке төсле тырпаеп торган яисә башка ябышкан колакка, табигать биргән төсен отыры Үзгәртми торган өлгергән борчактай соры, күк йөзе төсле зәңгәр күзлорга, хатын-кыз турында тәмсез мәзәк сөйләргә жстайланган чапылдык авызларга юлыгасың [Татар теленең язма корпусы];

Tуn-туры күзгә карап алулары, алсу битләре, матур колак яфраклары, аяз күк кебек зәцгәр күзләре, озын, бөгелеп торган керфекләре, аяк атлаулары...[Татар теленең язма корпусы];

Халкы да матур, егетләрнең күбесе озын буйлы, калын бәдәнле, кыю карашль; кыззлары елга камылшыдай зифа буйль, төпсез диңгез кебек зәңгәр күзлеләр [Татар теленең язма корпусы];

Чөенке борынль, сипкелле, күк әчү ташы кебек зәңгәр күзле, шомырт кара чәчле кыз бу озын чәчле ирнең ушын алды, күл өсте кебек 
зәңгәр хәзер аның күзләре [Татар теленең язма корпусы];

Остается летний день, шевеляший листочки, березки, белье, как облака, глаза, синие, как небо над облаками... [Национальный корпус русского языка];

Синие, как небо Памира, глаза Люды радостно сверкали, когда вбежала она в отдел археологии, бросила на стол две золотистые монетки и торжествующе сказала... [Национальный корпус русского языка];

Глаза у нее синие, как цветочки, $и$ смотрела она до слез доверчиво [Национальный корпус русского языка];

Наконец, она вздохнула и открыла синие, как фиалки, глаза [Национальный корпус русского языка];

И синие, синие, как воды родной реки, глаза девушки туманятся теперь слезами [Национальный корпус русского языка];

На щеках румянец, что маков цъвет. Глаза игривые, синие, как тропическое море [Национальный корпус русского языка].

Рус телендә югарыда әйтелгән образлардан тыш, үлем белән бәйле образлар да бар, алар бит, иреннәрне тасвирлаганда актив һәм кешенең эчке хис-кичерешләрен дә ассызыклый.

За окном еще темно, а внутри вагона от тусклых лампочек у всех лица синие, как у утопленников [Национальный корпус русского языка];

Однажды я подпльл к нему, с тревогой взглянул в белое, покачивающееся на воде лиио: шевельнулись синие, как у мертвеца, губы [Национальный корпус русского языка].

\section{Нәтижәләр}

Татар һәм рус телләрендә еш кулланыла торган төс компонентлы тотрыклы чагыштыруларны анализлау шундый нәтижәләргә китерде.

Татар һәм рус телләре материалында үткәрелгән тикшеренү кешенең тышкы кыяфәтен hәм эчке халәтен тасвирлау һәм бәяләү чарасы буларак, төс компонентлы чагыштыруларның күп булуын күрсәтте. Мондый чагыштыруларның төрлелеге кеше тормышындагы, әйләнә-тирәдәге төсле предмет, объектларның да гаять төрле булуы, аларның сөйләмдә актив кулланылуы белән дә бәйле.

Ике телдә дә чагыштыруларда иң еш очраган төсләр - ак һәм кара. Ак төс кешенең тышкы кыяфәтен (чәч, бит, тән төсе) генә түгел, аның күңел халәтен дә (курку, борчылу, авыру h.б.) чагылдыра. Татар телендә әлеге төс сафлык, чисталыкны сурәтләү өчен дә еш кулланыла.

Кара сүзе ярдәмендә чәч, күз, кашкерфекләр төсе сурәтләнә. Татар халкында кара күзле, кара чәчле кешеләр еш очраганга күрә, бу төс кергән чагыштырулар да татар телендә күбрәк.

Зәнъгәр һәм ямел төс ешрак күз төсенә нисбәттә, кайбер вакытта кешенең эчке кичерешләрен күрсәтү максатыннан, иреннәр, кул-аяклар h.б. тасвирлаганда да очрый.

Kbызыл компонентлы чагыштырулар күп вакыт иреннәрнең төсен, тулылыгын, матурлыгын күрсәтү өчен кулланыла. Рус телендәге чагыштыруларда әлеге төс ешрак очрый, чөнки красный (кызыл) красивый (матур) сүзенең синонимы буларак та йөри. Әлеге төс борын, күз, кул һәм аякларны тасвирлаганда язучының яки сөйләүченең негатив карашы ассызыклана.

Шулай итеп, чагыштыруларны анализлаган вакытта, беренчедән, чагыштыру объекты турында, икенчедән, чагыштыру өчен эталон булган предмет яки төшенчә турында мәгълүмат туплана. Чагыштыру нигезенә алынган билге чагыштыру объектында бик ачык белдерелә, шунлыктан әлеге билге аның характерлы сыйфатларыннан берсе булып тора. Текстта яки сөйләмдә мондый чагыштыруларны куллану, бер яктан, тасвирлана торган объектның төсен белдерсә, икенче яктан, әлеге чагыштыру кешенең уңай / тискәре физик яки психологик халәтенең сигналына да әйләнә. Эталонның төсе кешенең тышкы кыяфәтен, төсен генә ачыклап калмый, өстәмә мәгълүмат та бирә.

Тотрыклы чагыштырулар - дөнья тел сурәтен өйрәнү өчен ышанычлы объект һәм лингвомәдәни тикшеренүләр өчен продуктив чыганак, аларда халыкның дөньяга карашы чагылыш таба. Чөнки таныш булмаган әйберне сурәтләү өчен, кешеләр һәрвакытта да диярлек аны охшаш объект белән янәшә куялар. Кайвакыт эчке охшашлык та чагыштыру өчен нигез була, ягъни тышкы билгеләре буенча бөтенләй охшаш булмаган ике предмет яки төшенчә тәңгәлләштерелә. Тагын шуны да әйтергә кирәк, чагыштырган вакытта һәрвакыт диярлек субъектив бәя дә бирелә, тел берәмлегенә һәм аның аша чагыштырыла торган объектка карата телдә беркетелгән билгеле бер мөнәсәбәт тә чагылдырыла.

Чагыштыру күп вакытта кешеләрнең, ситуацияләрнең билгеле бер типтагы образларын тудыра. 
Татар һәм рус телләрендәге чагыштыруларга кешенең тышкы кыяфәтен тасвирлау өчен кулланылган образларның лексик-тематик төркемнәре охшашлыгы хас булуы ачыкланды. Бу кеше табигатенең һәм кеше фикерләвенең универсальлеге белән аңлатыла hәм, үз чиратында, әйләнә-тирә чынбарлыкны аңлауның бертөрле чагыштырулар ярдәмендә тасвирлануын күрсәтә. Ике телнең чагыштыруларында милли үзенчәлекле эталоннар булу һәр милләтнең мифологиясе, мәдәнияте, тарихы, әдәбияты белән, шулай ук билгеле бер милләт кешесенең индивидуаль күзаллавы белән бәйле.

\section{Әдәбият}

Гумбольдт В. Язык и философия культуры. М.: Прогресс, 1985. 450 c.

Замалетдинов Р.P. Татарская культура в языковом отражении. М: Гуманит. издат. центр ВЛАДОС; Казань: Магариф, 2004. 239 с.
Маслова В.A. Homolingualis в культуре: Монография. М.: Гнозис, 2007. 320 с.

Национальный корпус русского языка [Электронный ресурc]. URL: https://ruscorpora.ru/new (дата обращения: 26.08.2021).

Потебня А.А. Мысль и язык. Киев: СИНТО, 1993. $302 \mathrm{c}$.

Рамазанова Д.Б. Татар телендә кешегә бәйләнешле лексика. Казан: ИЯЛИ нәшр., 2013. 364 б.

Татар теленең аңлатмалы сүзлеге [Электрон pecypc]. URL: http://suzlek.antat.ru (мөрәжәгать итү вакыты: 26.08.2021).

Татар теленең аңлатмалы сүзлеге. Казан: Матбугат йорты, 2005. 848 б.

Татар теленең язма корпусы [Электрон ресурс]. URL: https://www.corpus.tatar (мөрәжәгать итү вакыты: 26.08.2021).

Толковый словарь Ожегова [Электронный pecypc]. URL: https://dic.academic.ru/contents.nsf/ ogegova/ (дата обращения: 26.08.2021).

\title{
СРАВНЕНИЯ С КОМПОНЕНТОМ «ЦВЕТ» КАК СРЕДСТВО ОЦЕНКИ ЧЕЛОВЕКА (НА МАТЕРИАЛЕ ТАТАРСКОГО И РУССКОГО ЯЗЫКОВ)
}

\author{
Рамзия Марсовна Болгарова, \\ Казанский федеральный университет, \\ Россия, 420008, г. Казань, ул. Кремлевская, д. 18, \\ ramzija5@yandex.ru. \\ Раушания Сагдатзяновна Нурмухаметова, \\ Казанский федеральный университет, \\ Россия, 420008, г. Казань, ул. Кремлевская, д. 18, \\ rsagadat@yandex.ru.
}

В данной статье в сопоставительном аспекте рассматриваются компаративные конструкции с колоративным компонентом в татарском и русском языках.

Целью данного исследования является изучение сравнительных конструкций с цветообозначениями в качестве средства описания и оценки внешнего вида человека. Материалами для исследования стали примеры из письменного корпуса татарского языка и национального корпуса русского языка. Исследуемые сравнительные конструкции используются для описания внешности людей, физического или психологического состояния человека. Данные изобразительные средства могут создавать положительный или отрицательный образ в зависимости от того, какой эталон лежит в основе сравнения.

Данные исследования могут быть использованы в преподавании русского и татарского языков, курса межкультурной коммуникации, составлении лингвокультурологических словарей и т. д.

Ключевые слова: татарский язык, русский язык, сравнения, колоративный компонент, внешний вид человека. 